Article

\title{
The Effect of Withdrawal Rate on Crystal Structure Perfection, Microstructure and Creep Resistance of Single Crystal Castings Made of CMSX-4 Nickel-Based Superalloy
}

\author{
Kamil Gancarczyk 1,2,*, Maciej Zubko ${ }^{3,4}{ }^{\oplus}$, Aneta Hanc-Kuczkowska ${ }^{3}$, Barbara Kościelniak 1,2, \\ Robert Albrecht ${ }^{3}$, Dariusz Szeliga ${ }^{1,2} \mathbb{D}$, Maciej Motyka ${ }^{1,2} \mathbb{C}$, Waldemar Ziaja ${ }^{1,2}$ and \\ Jan Sieniawski ${ }^{1,2}$ \\ 1 Department of Materials Science, The Faculty of Mechanical Engineering and Aeronautics, Rzeszow \\ University of Technology, 12 Powstancow Warszawy Ave., 35-959 Rzeszow, Poland; \\ b.koscielnia@prz.edu.pl (B.K.); dszeliga@prz.edu.pl (D.S.); motyka@prz.edu.pl (M.M.); \\ wziaja@prz.edu.pl (W.Z.); jansien@prz.edu.pl (J.S.) \\ 2 Research and Development Laboratory for Aerospace Materials, Rzeszow University of Technology, \\ 4 Zwirki i Wigury Str., 35-036 Rzeszow, Poland \\ 3 Institute of Materials Science, University of Silesia, 1a 75 Pulku Piechoty Str., 41-500 Chorzow, Poland; \\ maciej.zubko@us.edu.pl (M.Z.); aneta.hanc@us.edu.pl (A.H.-K.); robert.albrecht@us.edu.pl (R.A.) \\ 4 Department of Physics, University of Hradec Kralove, Rokitanshego 62/26 Str., 500-03 Hradec Kralove, \\ Czech Republic \\ * Correspondence: kamilgancarczyk@prz.edu.pl
}

Received: 12 September 2019; Accepted: 17 October 2019; Published: 19 October 2019

\begin{abstract}
This study focuses on the evaluation of the crystal structure perfection in the single crystal made of CMSX-4 nickel superalloy and its effect on creep resistance. Single crystal castings were manufactured by directional solidification process at the withdrawal rate of $1,3,5$ and $7 \mathrm{~mm} / \mathrm{min}$. Light (LM) and electron (SEM, TEM) microscopy, X-ray diffraction and Mossbauer spectroscopy were used for evaluation of the microstructure and crystal structure perfection. Castings were also subjected to creep tests. The best creep resistance was obtained for the casting manufactured at the withdrawal rate of $3 \mathrm{~mm} / \mathrm{min}$, characterized by the highest crystal structure perfection compared to the other castings examined.
\end{abstract}

Keywords: nickel-based superalloy; CMSX-4; single crystal (SX); crystal structure perfection; creep resistance

\section{Introduction}

Single crystal (SX) components (blades) of the hot section in aircraft engines are manufactured by directional solidification process. They are submitted to quality control, including the assessment of crystal orientation. The deviation angles between relevant crystallographic directions-required (for perfect crystal) and real-in produced SX casting are compared. These values are considered as main factors for evaluation of the degree of crystal structure perfection. The structure of SX casting is formed during solidification process of a single nucleus along one crystallographic direction. In most cases, it is the [001] direction, in order to provide high creep resistance. Therefore, creep behavior of a single crystal is determined by its structure perfection [1-6].

The technological process based on the Bridgman-Stockbarger method is the most commonly used in industry for manufacturing nickel-based superalloy single-crystal blades. It is composed of several stages: development of a three-dimensional 3D model of casting, preparation of a wax model, 
making a ceramic form, wax removal and annealing of the ceramic form, pouring liquid metal into the mold and conducting directional solidification. The process of directional solidification of nickel-based superalloy single crystals under the Bridgman (or Bridgman-Stockbarger) method is usually carried out in a vacuum furnace of vertical construction - the ceramic mold is slowly withdrawn from the heating zone [7-11].

A nickel-based CMSX-4 superalloy is used for fabrication the SX blades of high-pressure turbines working in extreme conditions in aircraft jet engines. The exceptional properties of the CMSX-4 superalloy are obtained due to its microstructure composed of two basic components- $\gamma$ and $\gamma^{\prime}$ phase crystals (Figure 1). The matrix is a solid solution, disordered $\gamma$ phase having cubic structure (cF4) with space group $(\mathrm{Fm} 3 \mathrm{~m})$ and lattice parameter $\mathrm{a}_{0 \gamma}=0.352 \mathrm{~nm}$. The intermetallic strengthening $\gamma^{\prime}$ phase $\mathrm{Ni} 3 \mathrm{Al}(\mathrm{Ti}, \mathrm{Ta})$ is partly ordered and characterized by a cubic crystal structure (cP4) with space group $(\mathrm{Pm} 3 \mathrm{~m})$ and lattice parameter $\mathrm{a}_{0 \gamma^{\prime}}=0.356 \mathrm{~nm}$ [12-17].

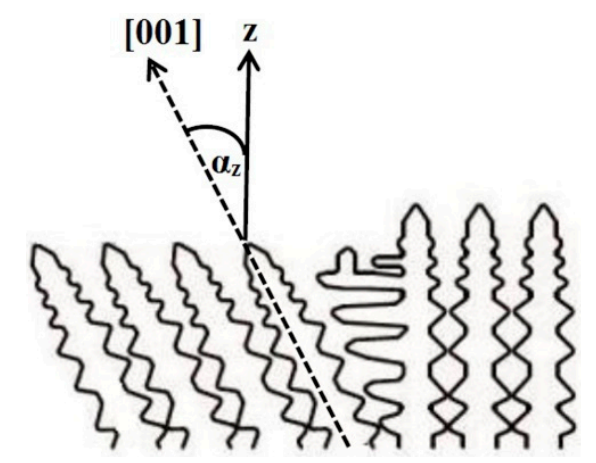

Figure 1. Angle $\alpha_{z}$ between crystallization and crystal [001] directions in a scheme of the dendritic structure.

Alloying elements of CMSX-4 superalloy can be classified in terms of their influence on the microstructure and properties:

- Strengthening of $\gamma$ solid solution-Co, Cr, Mo, Re, Ru and W,

- $\quad$ Forming precipitations of the strengthening phase $\gamma^{\prime}-\mathrm{Al}$, Ta and Ti.

The solidification process leads to heterogeneity of both chemical composition and microstructure. Increase of the withdrawal rate in the Bridgman process favors the segregation of alloying elements- $\mathrm{Al}$, $\mathrm{Ta}, \mathrm{Re}, \mathrm{Ti}$ and $\mathrm{W}$-and leads to heterogeneous precipitation of the strengthening $\gamma^{\prime}$ phase. The analysis of the literature data indicates that the withdrawal rate vw of SX blades under industrial conditions takes a value in the range from 1 to $5 \mathrm{~mm} / \mathrm{min}$ [18-20].

Creep resistance of SX turbine blades, especially used for the first stage of the turbine, can be improved by elimination of high-angle grain boundaries. Such structural parts are manufactured in the investment casting process carried out in a vacuum condition using multi-layered ceramic molds. It is of a great importance that solidification parameters-pouring temperature and withdrawal rate-of mold are precisely controlled and modified as needed. In order to achieve high quality of the products, continuous development of materials and components used in the technological process, such as wax models, ceramic molds and others, is required [21,22].

Moreover, another important factor that determines the creep resistance of a turbine blade is the single crystal orientation. The high creep strength of SX turbine blades requires that the direction of crystal withdrawal is parallel or only slightly deviated from the [001] crystallographic direction (deviation angle $\alpha_{z}$ ) [23]. The high deviation of the single crystal leads to a decrease in the mechanical properties of superalloys. Therefore, it is assumed that the value of the deviation angle $\alpha \mathrm{z}$ should be lower than $15^{\circ}$ [24].

The conditions of crystallization determine the occurrence of porosity and shrinkage in castings. Hence, the pore size is directly related to the crystallization conditions and microstructural parameters. 
It was found that the pore size increased with increasing withdrawal rate of the single crystal castings. Porosity determines the mechanical properties of SX castings made of nickel-based superalloy and it is an important evaluation criterion of their quality [25-30].

In this work, an assessment of the influence of crystallization process conditions-mainly the withdrawal rate- on the microstructure and crystal orientation of the SX casting was made. Test methods such as light microscopy, scanning and transmission electron microscopy, X-ray diffraction and Mossbauer spectroscopy were used for material characterization. The combination of these methods allowed for an accurate assessment of the microstructure of single crystals. Creep tests were also carried out to analyze the mechanical strength of produced castings. Obtained data can be useful for the selection of crystallization process conditions for nickel-based SX castings.

\section{Experimental}

Single crystal rods in the as-cast condition made of commercial CMSX-4 nickel-based superalloy (Table 1) were studied. The lost-wax casting method, including multilayer ceramic shell preparation, was used to obtain single crystal casting. The directional solidification process (based on the Bridgman method) was carried out in a vacuum furnace ALD VIM-IC 2 E/DS/SC (Hanau, Germany) at various withdrawal rates of $\mathrm{v}_{\mathrm{w}}=1,3,5$ and $7 \mathrm{~mm} / \mathrm{min}$. Before pouring, the mold had been heated up to the temperature of $1500^{\circ} \mathrm{C}$, for $2 \mathrm{~h}$. The temperature of liquid metal poured into the mold was $1550{ }^{\circ} \mathrm{C}$. The entire manufacturing process was carried out in the Department of Materials Science and Research and Development Laboratory for Aerospace Materials at Rzeszow University of Technology.

Table 1. The chemical composition of the CMSX-4 single crystal superalloy.

\begin{tabular}{cccccccccc}
\hline \multicolumn{10}{c}{ Element Content, \% wt. } \\
\hline $\mathrm{Cr}$ & $\mathrm{Co}$ & $\mathrm{Mo}$ & $\mathrm{W}$ & $\mathrm{Ta}$ & $\mathrm{Al}$ & $\mathrm{Ti}$ & $\mathrm{Hf}$ & $\mathrm{Re}$ & $\mathrm{Ni}$ \\
\hline 6.5 & 9 & 0.6 & 6 & 6.5 & 5.6 & 1 & 0.1 & 3 & bal. \\
\hline
\end{tabular}

Microstructure evaluation of the CMSX-4 superalloy in the as-cast condition was performed using light microscope (LM) Leica DMI3000M (Wetzlar, Germany) and scanning electron microscope (SEM) Hitachi S-3400N (Tokyo, Japan). Samples for LM and SEM observation were prepared by chemical etching in a solution containing $3 \mathrm{~g} \mathrm{MoO}_{3}, 100 \mathrm{~mL} \mathrm{HCl}, 100 \mathrm{~mL} \mathrm{HNO}_{3}$ and $100 \mathrm{~mL} \mathrm{H}_{2} \mathrm{O}$. The distance between primary dendrite arm spacing (PDAS) was measured for five images of the microstructure of one sample to determine its mean value.

The quantitative analysis of the microstructure was performed to determine the following: PDAS, surface area $S_{\gamma^{\prime}}$ and volume fraction $V_{\mathrm{v} \gamma^{\prime}}$ of $\gamma^{\prime}$ phase precipitates and number of the pores. Several LM and SEM microstructure images for each withdrawal rate were processed by the Leica Application Suite v3.7 software in accordance with procedures described in the literature [31]. The chemical composition of $\gamma^{\prime}$ phase was investigated by transmission electron microscope (TEM) JEOL JEM-3010 (Tokyo, Japan) equipped with EDS detector (Energy Dispersive X-ray Spectroscopy, Thermo Scientific, Waltham, MA, USA). For determining the lattice parameter of the $\gamma^{\prime}$ phase, the average radius of $\gamma^{\prime}$ phase atoms was calculated according to Formula (1) [32]:

$$
\mathrm{r}_{\mathrm{avg} \gamma^{\prime}}=\mathrm{c}_{\mathrm{Al} \gamma^{\prime}} \cdot \mathrm{r}_{\mathrm{Al}}+\mathrm{c}_{\mathrm{Cr} \gamma^{\prime}} \cdot \mathrm{r}_{\mathrm{Cr}}+\mathrm{c}_{\mathrm{Co} \gamma^{\prime}} \cdot \mathrm{r}_{\mathrm{Co}}+\mathrm{c}_{\mathrm{Mo} \gamma^{\prime}} \cdot \mathrm{r}_{\mathrm{Mo}}+\mathrm{c}_{\mathrm{Ti} \gamma^{\prime}} \cdot \mathrm{r}_{\mathrm{Ti}}+\mathrm{c}_{\mathrm{Ta} \gamma^{\prime}} \cdot \mathrm{r}_{\mathrm{Ta}}+\mathrm{c}_{\mathrm{Re} \gamma^{\prime}} \cdot \mathrm{r}_{\mathrm{Re}}+\mathrm{c}_{\mathrm{Hf} \gamma^{\prime}} \cdot \mathrm{r}_{\mathrm{Hf}}+\mathrm{c}_{\mathrm{Ni} \gamma^{\prime}} \cdot \mathrm{r}_{\mathrm{Ni}}
$$

where: $\mathrm{r}_{\mathrm{avg} \gamma^{\prime}}$-the average radius of the $\gamma^{\prime}$ phase atoms; $\mathrm{r}_{\mathrm{X}}$-average atom radius of element $\mathrm{X}: \mathrm{r}_{\mathrm{Al}}=$ $0.143 \mathrm{~nm}, \mathrm{r}_{\mathrm{Cr}}=0.125 \mathrm{~nm}, \mathrm{r}_{\mathrm{Co}}=0.125 \mathrm{~nm}, \mathrm{r}_{\mathrm{Mo}}=0.136 \mathrm{~nm}, \mathrm{r}_{\mathrm{Ti}}=0.145 \mathrm{~nm}, \mathrm{r}_{\mathrm{Ta}}=0.149 \mathrm{~nm}, \mathrm{r}_{\mathrm{Re}}=0.137$ $\mathrm{nm}, \mathrm{r}_{\mathrm{Hf}}=0.159 \mathrm{~nm}, \mathrm{r}_{\mathrm{Ni}}=0.125 \mathrm{~nm} ; \mathrm{c}_{X_{\gamma^{\prime}}}$-content of element $\mathrm{X}$ in $\gamma^{\prime}$ phase (\% at.).

The lattice parameter of $\gamma^{\prime}\left(\mathrm{a} \gamma^{\prime}\right)$ phase was calculated according to Formula (2):

$$
\mathrm{a} \gamma^{\prime}=\left(4 \cdot \operatorname{ravg} \gamma^{\prime}\right) / \sqrt{ } 2
$$


The parameter of long-range atomic order- $S_{d}$-of the $\gamma^{\prime}$ phase was determined by Mössbauer spectroscopy [33]. The value of this parameter depends on the specific location of the $\mathrm{Al}$, Ti and Ta atoms in the lattice of the $\gamma^{\prime}$ phase. The parameter $S_{d}=1$, if the $\gamma^{\prime}$ phase is completely ordered-Ni3Al(Ti,Ta). The value of $\mathrm{Sd}$ obtained from Mössbauer spectroscopy was applied to calculate probability $\mathrm{P}_{(\mathrm{Al}, \mathrm{Ti}, \mathrm{Ta})}$ of occupancy of the 000 atomic position in the crystal unit cell of the $\gamma^{\prime}$ phase by $\mathrm{Al}, \mathrm{Ti}$, Ta using Equation (3) [34]:

$$
\mathrm{P}_{(\mathrm{Al}, \mathrm{Ti}, \mathrm{Ta})}=\mathrm{S}_{\mathrm{d}}\left(1-\mathrm{C}_{(\mathrm{Al}, \mathrm{Ti}, \mathrm{Ta})}\right)+\mathrm{c}_{(\mathrm{Al}, \mathrm{Ti}, \mathrm{Ta})}
$$

where: $\mathrm{P}_{(\mathrm{Al}, \mathrm{Ti}, \mathrm{Ta})}$ - probability of occupancy of the 000 atomic position by $\mathrm{Al}, \mathrm{Ti}, \mathrm{Ta}$ atoms; $\mathrm{C}_{(\mathrm{Al}, \mathrm{Ti}, \mathrm{Ta})}$-atomic concentration in $\gamma^{\prime}$ phase; $\mathrm{S}_{\mathrm{d}}$-parameter of long-range order of atomic arrangement in the $\gamma^{\prime}$ phase.

Determination of the crystal orientation was conducted by an X-ray $\Omega$-scan method using OD-EFG diffractometer (EFG, Berlin, Germany) [35]. The value of the deviation angle $\alpha_{z}$ between the direction of the mold withdrawal and [001] crystal directions was measured (Figure 1).

Creep resistance of the CMSX-4 superalloy solidified at various withdrawal rates was determined using the Walter + Bai AG LFMZ-30 electromechanical creep machine (Löhningen, Switzerland). The creep tests and sample preparation were carried out in accordance with the requirements of ASTM E139-11. Specimen holders made of Inconel 713C nickel superalloy with a columnar microstructure were used. Specimens were heated in the furnace to $982{ }^{\circ} \mathrm{C}$ in air and held at this temperature for 60 minutes. After this time, they were loaded with a constant axial force, causing an initial tensile stress of $\sigma_{\mathrm{r}}=151.8 \mathrm{MPa}$. The temperature during the creep test was measured by 3 S-type PtRh10-Pt thermocouples.

\section{Results and Discussion}

LM analysis confirmed the dendritic microstructure in the castings manufactured at a withdrawal rate of 1,3,5 and $7 \mathrm{~mm} / \mathrm{min}$ (Figure 2). The distance between the primary dendrite arm spacing (PDAS) was measured as follows (standard deviation): 457 (13), 376 (20), 321 (18) and 386 (15) $\mu \mathrm{m}$ for 1, 3, 5 and $7 \mathrm{~mm} / \mathrm{min}$, respectively. The increase in the withdrawal rate from 1 to $5 \mathrm{~mm} / \mathrm{min}$ caused a decrease in PDAS. For $7 \mathrm{~mm} / \mathrm{min}$, PDAS was higher than expected but it should be noted that the standard deviation of the measured value was in the range of 13-20 $\mu \mathrm{m}$. It was found, based on microstructure analysis (Figure 2), that for a higher withdrawal rate, more dendrites with tertiary arms grew. However, they were not observed in castings manufactured at $1 \mathrm{~mm} / \mathrm{min}$.
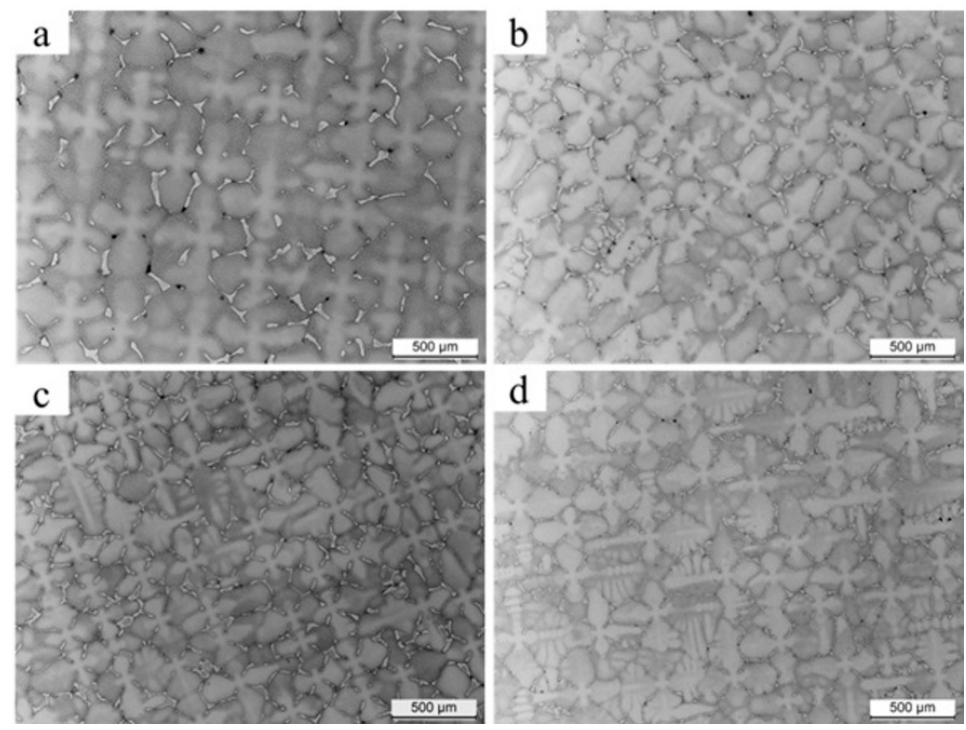

Figure 2. Dendritic microstructure (LM) of CMSX-4 superalloy solidified at different withdrawal rate: (a) 1 , (b) 3 , (c) 5 and (d) $7 \mathrm{~mm} / \mathrm{min}$. 
The SEM observation revealed the presence of the $\gamma^{\prime}$ phase in microstructure of castings. In all cases, the $\gamma^{\prime}$ precipitates were characterized by different, polyhedral morphology in dendritic and interdendritic regions. It was found that the increase in the withdrawal rate led to a decrease in the size of the $\gamma^{\prime}$ precipitates (Figure 3).
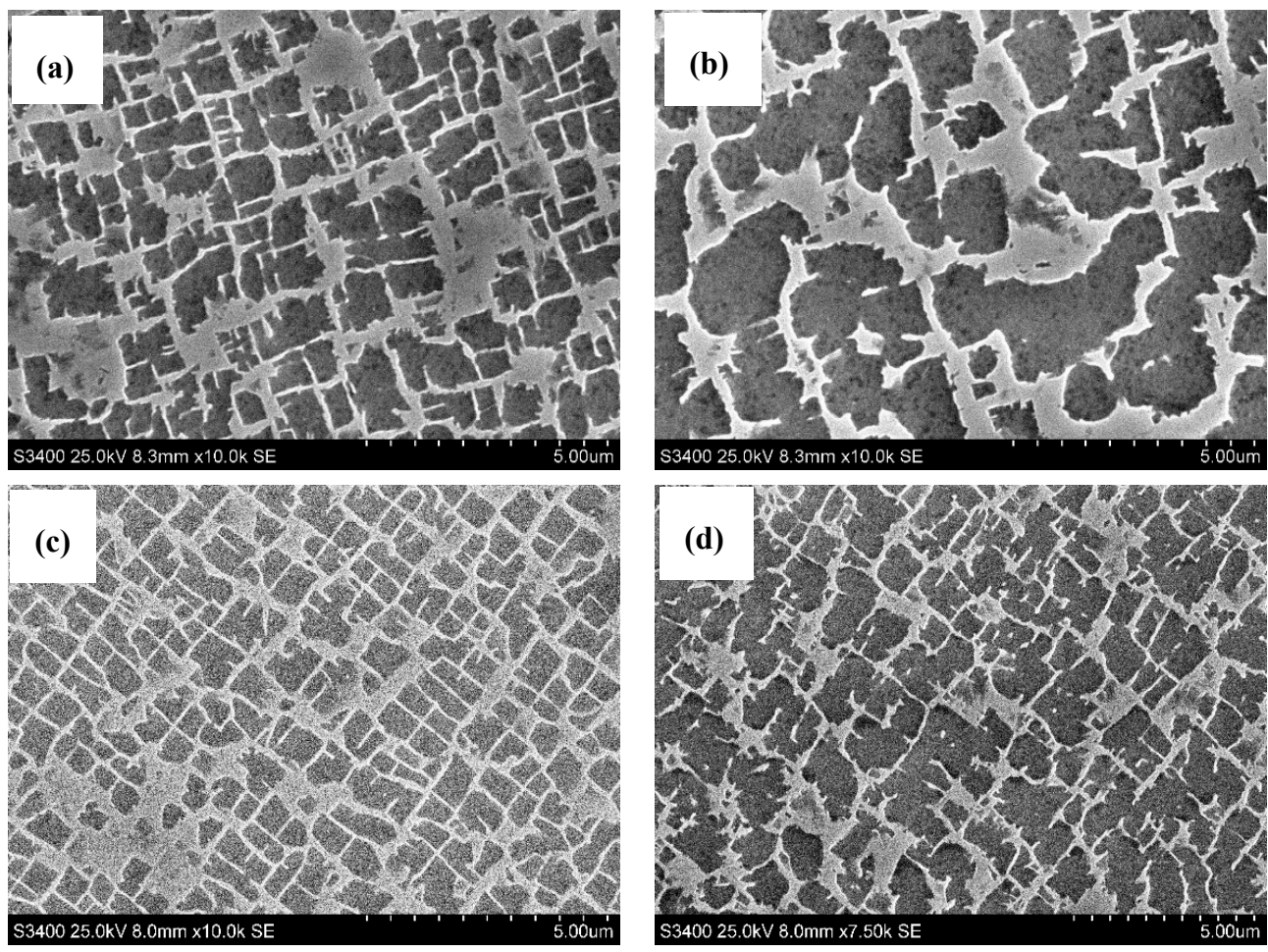

(e)
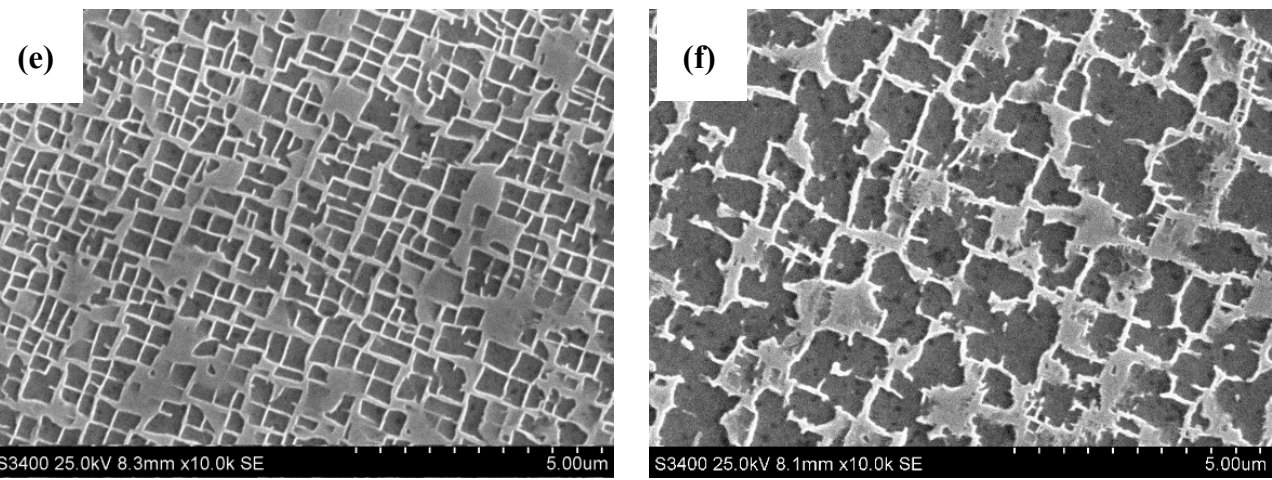

(g)

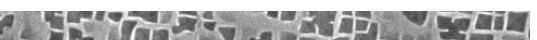

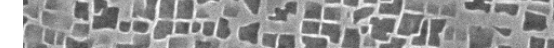

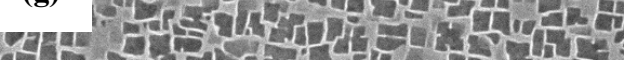

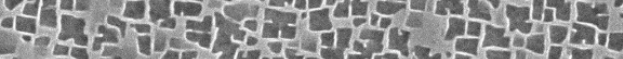

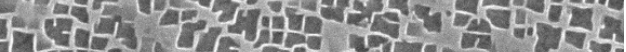
जी

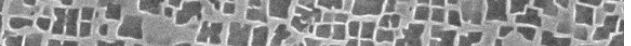

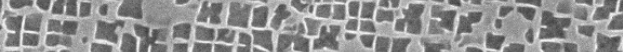

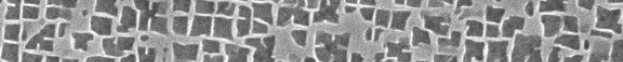

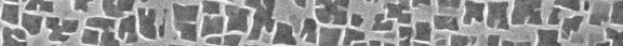

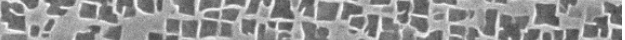
$-4,5$ in

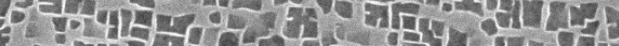

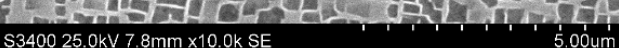

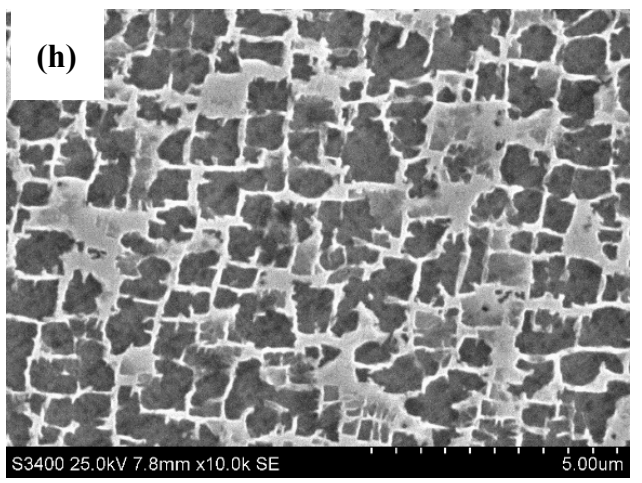

Figure 3. Morphology of $\gamma^{\prime}$ precipitates in the matrix of $\gamma$ phase in CMSX-4 superalloy solidified at different withdrawal rates: (a) 1, (c) 3, (e) 5 and (g) $7 \mathrm{~mm} / \mathrm{min}$-dendritic region, (b) 1, (d) 3, (f) 5 and (h) $7 \mathrm{~mm} / \mathrm{min}$-interdendritic region. 
Stereological parameters of $\gamma^{\prime}$ precipitates were determined using binary images (Figure 4). Castings withdrawn with the rate of $1 \mathrm{~mm} / \mathrm{min}$ are characterized by average values of the $\gamma^{\prime}$ precipitate surface area $S \gamma^{\prime}=0.64 \mu \mathrm{m}^{2}$ and the largest difference between its minimum and maximum values (2.03 $\mu \mathrm{m}^{2}$ —dendritic; $6.12 \mu \mathrm{m}^{2}$-interdendritic region) (Table 1). In the castings manufactured at a withdrawal rate of $3 \mathrm{~mm} / \mathrm{min}$, the $S \gamma^{\prime}=0.31 \mu \mathrm{m}^{2}$ - half of the value obtained at $1 \mathrm{~mm} / \mathrm{min}$. The smallest scatter of $S \gamma^{\prime}$ values $\left(0.35 \mu \mathrm{m}^{2}\right.$, Table 1$)$ was found in the microstructure of castings withdrawn at the rate of $5 \mathrm{~mm} / \mathrm{min}$ in the dendritic region. The size of $\gamma^{\prime}$ precipitates decreased significantly with an increase in the withdrawal rate from 1 to $5 \mathrm{~mm} / \mathrm{min}$; the difference between data calculated for 5 and $7 \mathrm{~mm} / \mathrm{min}$ is much smaller (Table 1). The sizes of precipitations of $\gamma^{\prime}$ are bigger in the interdendritic region then in dendrite one for $1,3,5$ and $7 \mathrm{~mm} / \mathrm{min}$ castings.

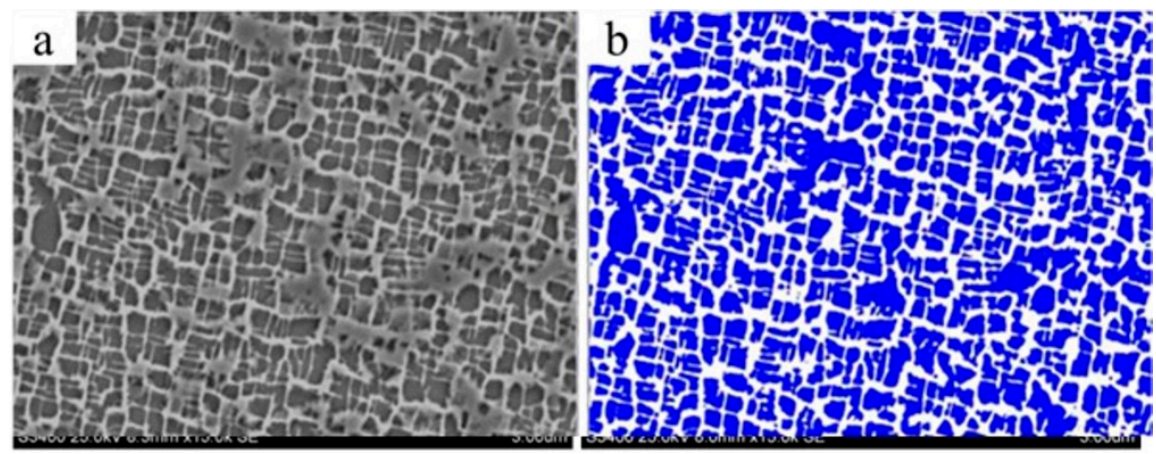

Figure 4. An example of image processing (binarization) to determine the volume fraction of microstructure constituents: (a) initial greyscale image (for microstructure of casting withdrawn at the rate of $1 \mathrm{~mm} / \mathrm{min})$, (b) binary image.

The highest volume fraction of the $\gamma^{\prime}$ phase precipitations was found in the casting withdrawn at the rate of $5 \mathrm{~mm} / \mathrm{min}-\mathrm{V}_{\mathrm{V} \gamma^{\prime}}=64.6 \%$ (58.7-dendritic; 68.7-interdendritic region) (Table 2). Then, for casting at a withdrawal rate $1 \mathrm{~mm} / \mathrm{min}$ and the smallest volume fractions were found for 3 and $7 \mathrm{~mm} / \mathrm{min}$. A small difference in the $\mathrm{V}_{\mathrm{V} \gamma^{\prime}}$ average values_about $5 \%$-and high values of standard deviation for $7 \mathrm{~mm} / \mathrm{min}$ (11.1) make it not possible to evaluate the effect of the withdrawal rate on the volume fraction of $\gamma^{\prime}$ precipitations (Table 2). The volume fraction of $\gamma^{\prime}$ is bigger in the interdendritic region than the dendritic in castings at withdrawal rates of $1,3,5$ and $7 \mathrm{~mm} / \mathrm{min}$. Additionally, the accuracy of such measurements strongly depend on subjective assessment in the image binarization process (Figure 4).

Table 2. Volume fraction and surface area of $\gamma^{\prime}$ phase precipitates in CMSX-4 superalloy in the as-cast state, depending on the rate of single crystal withdrawal.

\begin{tabular}{|c|c|c|c|c|c|c|c|c|c|}
\hline \multirow{3}{*}{$\begin{array}{l}\text { Withdrawal } \\
\text { Rate } \mathbf{v}_{\mathbf{w}} \\
\text { mm/min }\end{array}$} & \multicolumn{3}{|c|}{ Relative Volume of $\gamma^{\prime}$ Phases $V_{V_{\gamma^{\prime}}, \%}$} & \multicolumn{6}{|c|}{ Surface Area of $\gamma^{\prime}$ Phase $S_{\gamma^{\prime}}, \mu \mathrm{m}^{2}$} \\
\hline & \multirow{2}{*}{ Average } & \multirow{2}{*}{ Dendritic } & \multirow{2}{*}{$\begin{array}{l}\text { Interdendritic } \\
\text { Region }\end{array}$} & \multicolumn{3}{|c|}{ Dendritic } & \multicolumn{3}{|c|}{ Interdendritic Region } \\
\hline & & & & Min & Max & Ave & Min & Max & Ave \\
\hline 1 & $61.1(0.6)$ & 55.1 & 69.2 & 0.05 & 2.08 & 0.64 & 0.08 & 6.2 & 1.13 \\
\hline 3 & $59.9(2.0)$ & 54.8 & 65.8 & 0.09 & 1.0 & 0.31 & 0.09 & 4.1 & 0.55 \\
\hline 5 & $64.6(3.7)$ & 58.7 & 68.7 & 0.07 & 0.35 & 0.16 & 0.05 & 3.7 & 0.53 \\
\hline 7 & 59.9 (11.1) & 60.1 & 65.2 & 0.02 & 0.38 & 0.09 & 0.05 & 3.4 & 0.46 \\
\hline
\end{tabular}

The chemical composition of the $\gamma^{\prime}$ phase was determined by the EDS method. Among alloying elements of CMSX-4 superalloy, those which form the $\gamma^{\prime}$ phase were separately analysed-Ni, $\mathrm{Al}$, $\mathrm{Ti}$ and Ta (Table 3). The total content of $\mathrm{Al}$, Ti and Ta in the $\gamma^{\prime}$ phase decreased with an increase in the withdrawal rate from 1 to $5 \mathrm{~mm} / \mathrm{min}$ (Table 3). The content of $\mathrm{Ni}$ in the $\gamma^{\prime}$ phase was the highest at a withdrawal rate of $3 \mathrm{~mm} / \mathrm{min}-76.23 \%$ at. Then, for withdrawal rates of 1 and $7 \mathrm{~mm} / \mathrm{min}$, the value 
of nickel is similar-around $75 \%$. The lowest amount of nickel was found in the casting made at the withdrawal rate of $5 \mathrm{~mm} / \mathrm{min}$.

Table 3. Chemical composition of the $\gamma^{\prime}$ phase in CMSX-4 superalloy.

\begin{tabular}{cccccc}
\hline & & \multicolumn{4}{c}{ Withdrawal Rate vw, mm/min } \\
\cline { 3 - 6 } & & $\mathbf{1}$ & $\mathbf{3}$ & $\mathbf{5}$ & $\mathbf{7}$ \\
\cline { 3 - 6 } & $\mathrm{Cr}$ & $2.5(0.5)$ & $2.3(0.7)$ & $5.4(2.8)$ & $3.2(1.1)$ \\
& $\mathrm{Co}$ & $7.3(0.4)$ & $8.2(0.5)$ & $10.09(2.3)$ & $8.2(0.8)$ \\
Elements & $\mathrm{Mo}$ & $0.3(0.2)$ & $0.3(0.1)$ & $0.5(0.2)$ & $0,1(0.1)$ \\
content in $\gamma^{\prime}$ & $\mathrm{W}$ & $0.9(0.1)$ & $1.1(0.1)$ & $3.5(1.0)$ & $2,2(0.4)$ \\
phase, \% at. & $\mathrm{Ta}$ & $1.7(0.2)$ & $1.5(0.3)$ & $4.0(1.3)$ & $5.4(0.5)$ \\
(standard & $\mathrm{Re}$ & $0.3(0.1)$ & $0.2(0.1)$ & $1.9(0.9)$ & $0.4(0.1)$ \\
deviation) & $\mathrm{Al}$ & $10.6(0.5)$ & $8.5(1.4)$ & $3.7(0.9)$ & $4.5(0.3)$ \\
& $\mathrm{Ti}$ & $1.1(0.2)$ & $1.1(0.15)$ & $0.7(0.3)$ & $1.1(0.2)$ \\
& $\mathrm{Ni}$ & $75.3(1.0)$ & $76.2(1.4)$ & $70.2(4.9)$ & $75.1(0.6)$ \\
& $\mathrm{Al}+\mathrm{Ta}+\mathrm{Ti}$ & 13.4 & 11.1 & 10.4 & 12.7 \\
\hline
\end{tabular}

The calculated values of the lattice parameter of the phases indicate that the $\mathrm{a}_{\gamma^{\prime}}$ decreases with the increase in the withdrawal rate. The values of the $a_{\gamma}$ were the highest for the withdrawal rate of $3 \mathrm{~mm} / \mathrm{min}$. It was then reduced for withdrawal rates of 7,5 and $1 \mathrm{~mm} / \mathrm{min}$. The largest difference between the $\mathrm{a}_{\gamma}$ and $\mathrm{a}_{\gamma^{\prime}}$ values was found for a withdrawal rate of $1 \mathrm{~mm} / \mathrm{min}$, the smallest was observed for $7 \mathrm{~mm} / \mathrm{min}$ (Table 4).

Table 4. Lattice parameter of the $\gamma$ and $\gamma^{\prime}$ phases.

\begin{tabular}{ccc}
\hline \multirow{2}{*}{ Withdrawal Rate $\mathbf{v w}, \mathbf{m m} / \mathbf{m i n}$} & \multicolumn{2}{c}{ Lattice Parameter $\mathbf{a}, \mathbf{n m}$ (Standard Deviation) } \\
\cline { 2 - 3 } & $\mathbf{a}_{\boldsymbol{\gamma}}$ & $\mathbf{a}_{\boldsymbol{\gamma}^{\prime}}$ \\
\hline 1 & $0.3563(0.0005)$ & $0.3604(0.0006)$ \\
3 & $0.3571(0.0012)$ & $0.3604(0.0008)$ \\
5 & $0.3568(0.0004)$ & $0.3594(0.0011)$ \\
7 & $0.3564(0.0008)$ & $0.3589(0.0008)$ \\
\hline
\end{tabular}

On the basis of the Mössbauer spectroscopy analysis, it was found that the values of the $\mathrm{S}_{\mathrm{d}}$ parameter (the long-range order of atomic arrangement) are similar for the withdrawal rates 1-5 $\mathrm{mm} / \mathrm{min}$ - about 0.4 (Figure 5). A significantly lower value was determined for casting withdrawn at the rate of $7 \mathrm{~mm} / \mathrm{min}$. The probability of occupancy of the 000 atomic position shows that the most ordered $\gamma^{\prime}$ phase is present in castings withdrawn at the rate of $1-5 \mathrm{~mm} / \mathrm{min}$-from 0.45 to 0.48 (Figure 5). Less order was observed for casting crystalized at the withdrawal rate $7 \mathrm{~mm} / \mathrm{min}-0.36$ (Figure 5). It seems that the ordering of the $\gamma^{\prime}$ phase decreases when the withdrawal rate in the Bridgman process is greater than $3 \mathrm{~mm} / \mathrm{min}$.

The obtained results showed that the $\gamma^{\prime}$ phase in the CMSX-4 nickel-based superalloy is not completely ordered. It consists of a part of the ordered phase with the Pm3m space group and the disordered solid solution with the Fm3m space group. 


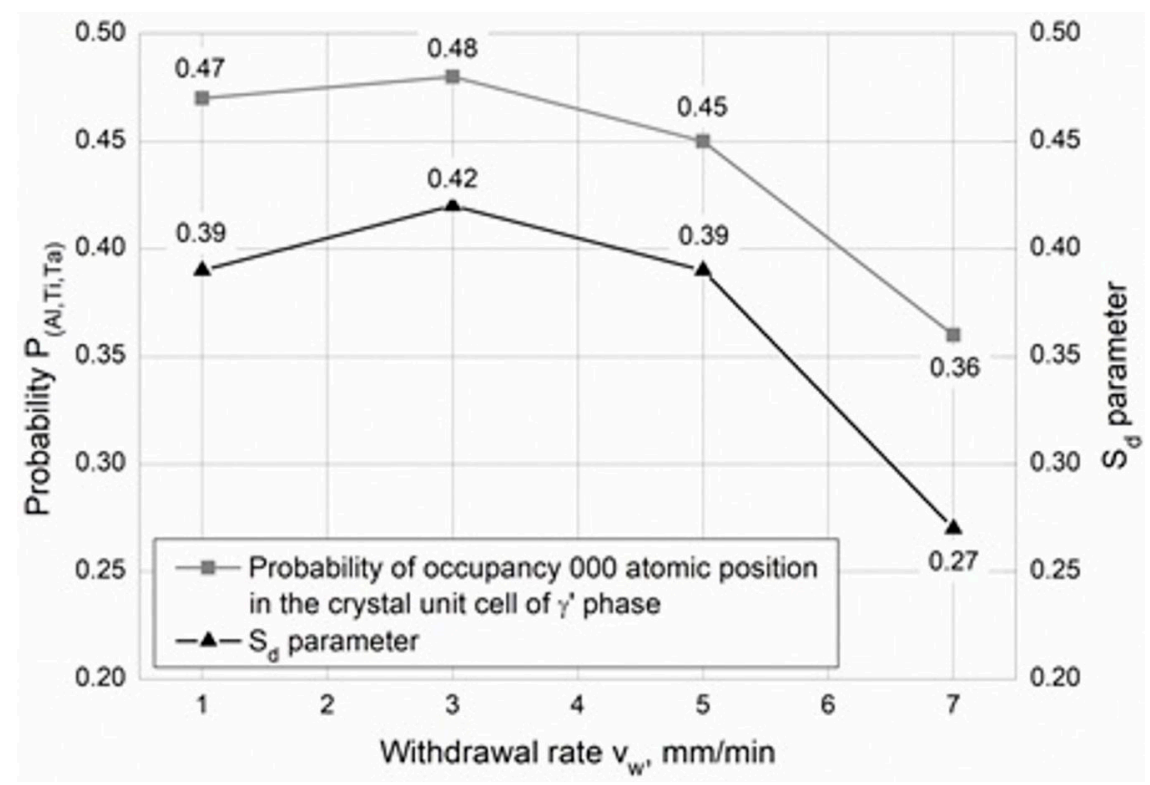

Figure 5. Values of probability of occupancy of the 000 atomic position by $\mathrm{Al}, \mathrm{Ti}$ and $\mathrm{Ta}$ and $\mathrm{S}_{\mathrm{d}}$ parameters as a function of the withdrawal rate.

The crystal orientation determined by the $\Omega$-scan method on the cross-sections of castings showed that the $\alpha_{z}$ angle for all four investigated withdrawal rates takes values well below the acceptable maximum of $15^{\circ}$ (Table 5). Castings differ between the minimum and maximum values of the $\alpha_{z}$ angle measured on the casting cross-sections. For the casting made at a withdrawal rate of $1 \mathrm{~mm} / \mathrm{min}$, the $\alpha_{z}$ angle takes the values in the range from $5.7^{\circ}$ to $9.6^{\circ}$ (Figure 6a). Hence, the scatter of this angle on the analyzed surface was $3.9^{\circ}$. For the casting produced at $3 \mathrm{~mm} / \mathrm{min}$, the $\alpha_{z}$ angle takes the value from $7^{\circ}$ to $8.3^{\circ}$-the difference was $1.3^{\circ}$ (Figure $6 \mathrm{~b}$ ). A similar difference between the minimum and the maxim $\alpha_{z}$ was for a withdrawal rate of $5 \mathrm{~mm} / \mathrm{min}$, where the $\alpha_{z}$ angle $\min =4.9$ and $\max =6.2^{\circ}$ (Figure $6 \mathrm{c}$ ). For a withdrawal rate of $7 \mathrm{~mm} / \mathrm{min}, \alpha_{\mathrm{z}}$ ranges from $5.1^{\circ}$ to $7.6^{\circ}$ (Figure $6 \mathrm{~d}$ ). In summary, the withdrawal rate did not affect the value of the $\alpha \mathrm{z}$ angle in single crystal castings.

Table 5. Value of $\alpha \mathrm{z}$ angle $\left[{ }^{\circ}\right]$ between the [001] crystal direction and the direction of mold withdrawal.

\begin{tabular}{cccccccccccc}
\hline \multicolumn{10}{c}{ Withdrawal Rate vw, mm/min } \\
\hline \multicolumn{10}{c}{1} & \multicolumn{10}{c}{5} & 5 & \\
\hline$\alpha_{\mathrm{z}} \min$ & $\alpha_{\mathrm{z}} \max$ & $\Delta \alpha_{\mathrm{z}}$ & $\alpha_{\mathrm{z}} \min$ & $\alpha_{\mathrm{z}} \max$ & $\Delta \alpha_{\mathrm{z}}$ & $\alpha_{\mathrm{z}} \min$ & $\alpha_{\mathrm{z}} \max$ & $\Delta \alpha_{\mathrm{z}}$ & $\alpha_{\mathrm{z}} \min$ & $\alpha_{\mathrm{z}} \max$ & $\Delta \alpha_{\mathrm{z}}$ \\
5.7 & 9.6 & 3.9 & 7.0 & 8.3 & 1.3 & 4.9 & 6.3 & 1.4 & 5.1 & 7.6 & 2.5 \\
\hline
\end{tabular}


a)

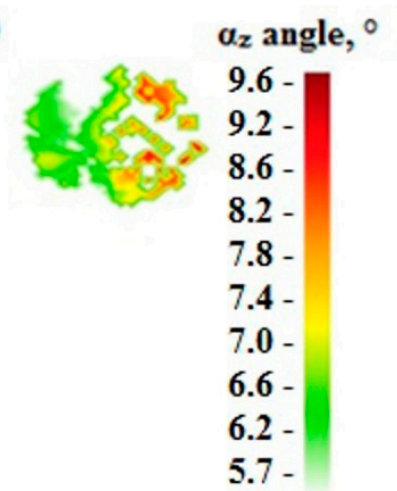

c)

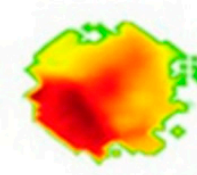

$6.3-$
$6.15-$
$6.0-$
$5.85-$

$5.7-$

$5.55-$

$5.4-$

$5.25-$

$5.1-$

$4.9-$ b)

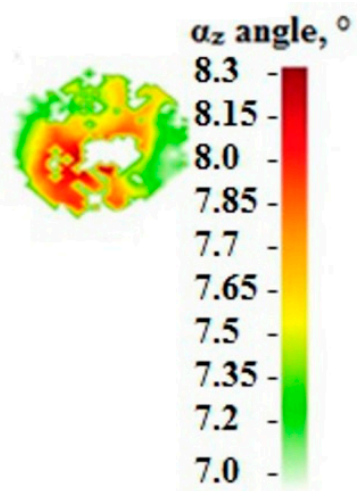

d)

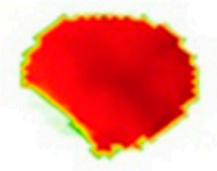

Figure 6. The values of the $\alpha \mathrm{z}$ angle on the surface of cross-section of the CMSX-4 superalloy casting withdrawn at the rate of: (a) $1,(\mathbf{b}) 3$, (c) 5, (d) $7 \mathrm{~mm} / \mathrm{min}$.

Analysis of the porosity (Figure 7) showed significant differences in the number on the surface of pores in $1.4 \mathrm{~mm}^{2}$ area and their size (Figure 8). The largest number of pores, with a surface area of up to $10 \mu \mathrm{m}^{2}$, was found in a casting made at the withdrawal rate of $1 \mathrm{~mm} / \mathrm{min}$. Castings produced at the withdrawal rate of $7 \mathrm{~mm} / \mathrm{min}$ also contained a large number of pores; however, fewer than in the $1 \mathrm{~mm} / \mathrm{min}$ casting. The lowest number of pores was found in the castings withdrawn at the rate of 3 and $5 \mathrm{~mm} / \mathrm{min}$. The biggest pores $\left(41-50 \mu \mathrm{m}^{2}\right)$ - the larger the pores the greater the reduction in the mechanical properties-were detected in castings withdrawn at rate of $1 \mathrm{~mm} / \mathrm{min}$ only (Figure 9). 
a)

$200 \mu \mathrm{m}$

c)

$200 \mu \mathrm{m}$ b)

$200 \mu \mathrm{m}$

d)

$200 \mu \mathrm{m}$

Figure 7. Micrographs of pores of cross-section of the CMSX-4 superalloy casting withdrawn at the rate of: (a) 1, (b) 3, (c) 5 , (d) $7 \mathrm{~mm} / \mathrm{min}$.

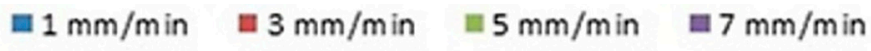

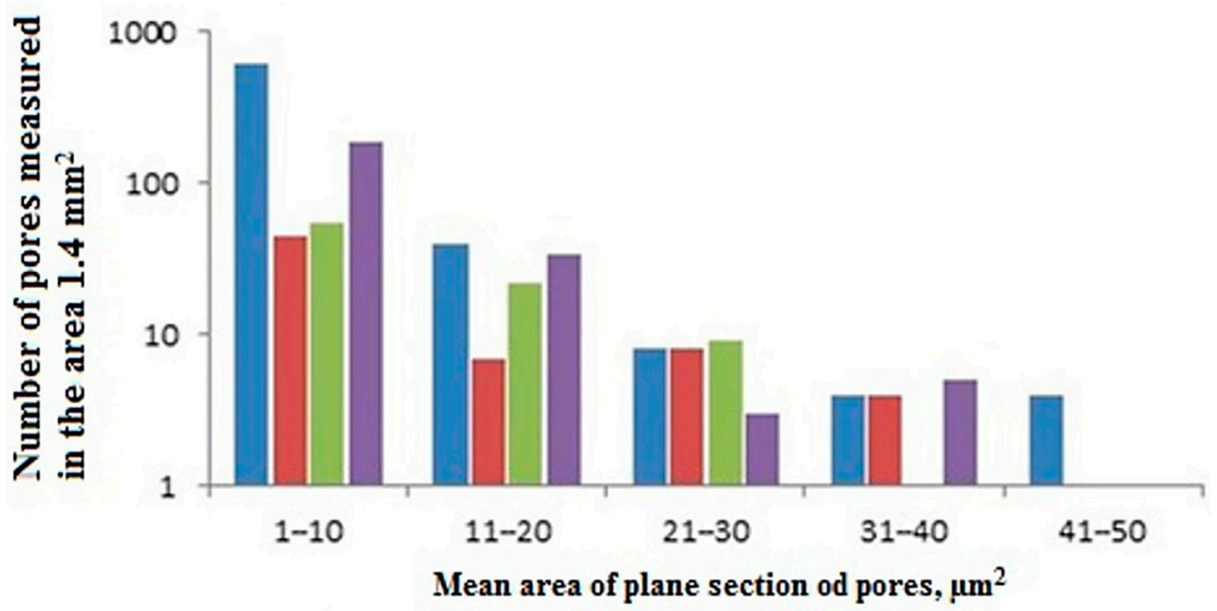

Figure 8. The number of pores and their average area measured in the cross-section of the single crystal (SX) castings. 


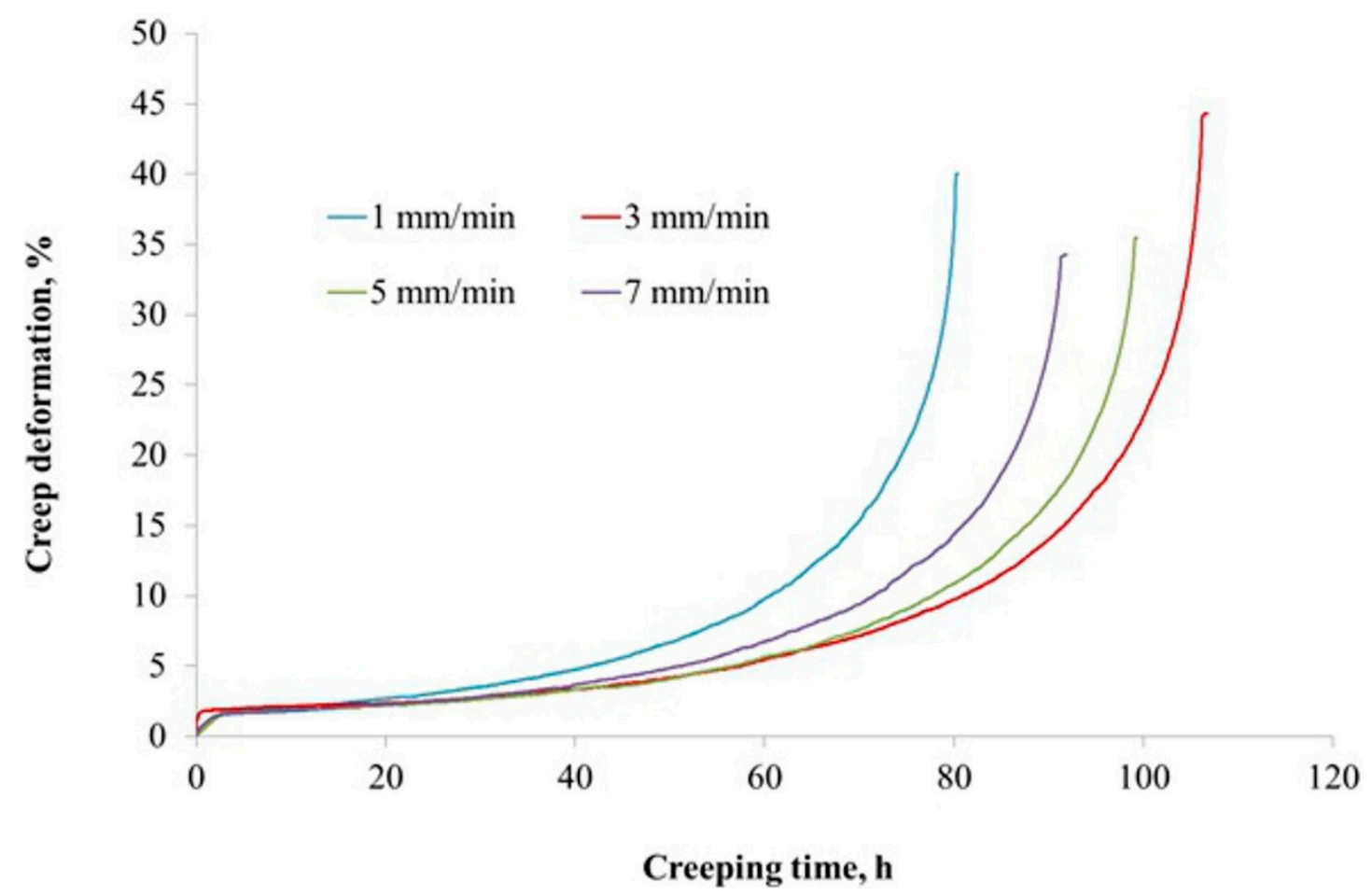

Figure 9. Creep curves of single crystal castings.

Creep tests showed differences between the castings both in terms of time to failure and total creep deformation. The longest creep life was found for the casting solidified at a withdrawal rate of $3 \mathrm{~mm} / \mathrm{min}-111 \mathrm{~h}$. The measured creep deformation was $44 \%$. The casting with a withdrawal rate at $5 \mathrm{~mm} / \mathrm{min}$ was broken after a test duration of $102 \mathrm{~h}$ and the measured creep deformation was $35 \%$. For the $7 \mathrm{~mm} / \mathrm{min}$ casting, the creep time was $94 \mathrm{~h}$ and the creep deformation, approximated as for $5 \mathrm{~mm} / \mathrm{min}$, was $34 \%$. The shortest time for sample destruction to occur $(83 \mathrm{~h})$ was found in the sample for casting $1 \mathrm{~mm} / \mathrm{min}$ and the creep deformation was equal to $40 \%$ (Figure 9). Creep life data obtained for various castings coincided with the results of the porosity analysis. The casting produced at the withdrawal rate of $1 \mathrm{~mm} / \mathrm{min}$ that showed the largest number of pores on its surface, exhibited the shortest time to failure in the creep test. The casting produced at the withdrawal rate of $3 \mathrm{~mm} / \mathrm{min}$, which showed the lowest number of pores on its surface, was characterized by the longest creep time. Hence, it can be concluded that its porosity had the greatest influence on the creep strength of the casting.

The microstructure of a CMSX-4 superalloy depends on the conditions of solidification, which are determined by the casting production process. In the Bridgman method, the temperature gradient and cooling rate are much lower than in the LMC method. An increase of these solidification parameters leads to a refinement of the microstructure and a reduction of the primary dendrites arm spacing (PDAS). PDAS determines the size of the pores that form under the solidification of the mushy zone. It is well known that the shape and size of the pores have a decisive impact on the mechanical properties of nickel-based superalloy castings. The high-cycle fatigue life of castings increases significantly for PDAS $=250 \mu \mathrm{m}$, which is refined by the LMC method [36-38]. In the presented study, the highest creep resistance was detected for castings withdrawn with the rate of 3 and $5 \mathrm{~mm} / \mathrm{min}$ (Figure 9), characterized by the smallest PDAS values (376 and $321 \mu \mathrm{m}$ respectively) and porosity (Figure 8).

\section{Conclusions}

The crystal structure perfection of the CMSX-4 superalloy was evaluated for castings manufactured at the withdrawal rate of $1,3,5$ and $7 \mathrm{~mm} / \mathrm{min}$ using microscopic, X-ray $\Omega$-scan and Mössbauer 
spectroscopy methods. The effect of the level of the crystal structure perfection on creep behavior was also analyzed. Based on the obtained results, the following conclusions can be formulated:

1. Porosity has the greatest impact on the creep resistance of single crystal castings. Increased pore content leads to reduced creep resistance. Castings containing a large number of pores are broken after a shorter time.

2. The withdrawal rate of castings in the employed range $(1-7 \mathrm{~mm} / \mathrm{min})$ does not affect the crystal orientation. For each adopted withdrawal rate, the casting was obtained in the [001] crystal orientation $\left(\alpha_{\mathrm{z}}<15^{\circ}\right)$.

3. There was no influence of withdrawal rate on the volume fraction of the $\gamma^{\prime}$ phase. The volume fraction of this phase in "as-cast" CMSX-4 superalloy is close to approximately $60 \%$.

4. The value of the lattice parameter $\mathrm{a}_{0 \gamma^{\prime}}$ decreases with the increase in the withdrawal rate.

Author Contributions: Conceptualization, K.G. and W.Z.; methodology, M.Z., A.H.-K. and M.M.; validation, J.S.; formal analysis, D.S.; investigation, K.G., M.Z., A.H.-K., B.K. and R.A.; writing-original draft preparation, K.G.; writing—review and editing, M.M.; visualization, W.Z. and M.M.; supervision, J.S.; project administration, K.G.

Funding: This work was supported by the National Science Centre Poland (NCN) under Grant No. Preludium-UMO-2016/21/N/ST8/00240.

Conflicts of Interest: The authors declare no conflict of interest.

\section{References}

1. Reed, R.C. The Superalloys, Fundamentals and Applications; Cambridge University Press: Cambridge, UK, 2006.

2. Durand-Charre, M. The Microstructure of Superalloys; Gordon and Breach Science Publishers: London, UK, 2003.

3. Szeliga, D.; Gancarczyk, K.; Ziaja, W. The Control of Solidification of Ni-Based Superalloy Single-Crystal Blade by Mold Design Modification using Inner Radiation Baffle. Adv. Eng. Mater. 2018, 20, 1700973. [CrossRef]

4. Pollock, T.M.; Tin, S. Nickel-Based Superalloys for Advanced Turbine Engines: Chemistry, Microstructure and Properties. J. Propuls. Power 2006, 22, 361-374. [CrossRef]

5. Nowak, W.J.; Ochał, K.; Wierzba, P.; Gancarczyk, K.; Wierzba, B. Effect of Substrate Roughness on Oxidation Resistance of an Aluminized Ni-Base Superalloy. Metals 2019, 9, 782. [CrossRef]

6. Zhu, Q.; Chen, G.; Wang, C.; Qin, H.; Zhang, P. Tensile Deformation and Fracture Behaviors of a Nickel-Based Superalloy via In Situ Digital Image Correlation and Synchrotron Radiation X-ray Tomography. Materials 2019, 12, 2461. [CrossRef] [PubMed]

7. Zhang, P.; Zhu, Q.; Chen, G.; Qin, H.; Wang, C. Effect of Heat Treatment Process on Microstructure and Fatigue Behavior of a Nickel-Base Superalloy. Materials 2015, 8, 6179-6194. [CrossRef]

8. Papadaki, C.; Li, W.; Korsunsky, A.M. On the Dependence of $\gamma^{\prime}$ Precipitate Size in a Nickel-Based Superalloy on the Cooling Rate from Super-Solvus Temperature Heat Treatment. Materials 2018, 11, 1528. [CrossRef]

9. Dai, H.J.; Dong, H.B.; D'Souza, N.; Gebelin, J.-C.; Reed, R.C.; Dong, H. Grain Selection in Spiral Selectors During Investment Casting of Single-Crystal Components: Part II. Numerical Modeling. Met. Mater. Trans. A 2011, 42, 3439-3446. [CrossRef]

10. Dai, H.J.; Gebelin, J.-C.; D'Souza, N.; Brown, P.D.; Dong, H. Effect of spiral shape on grain selection during casting of single crystal turbine blades. Int. J. Cast Met. Res. 2009, 22, 54-57. [CrossRef]

11. Brundidge, C.L.; van Drasek, D.; Wang, B.; Pollock, T.M. Structure refinement by a liquid metal cooling solidification process for single-crystal nickel-base superalloys. Metall. Mater. Trans. 2012, 43, 965-976. [CrossRef]

12. Szeliga, D.; Ziaja, W.; Motyka, M.; Kubiak, K.; Sieniawski, J. Application of Inner Radiation Baffles in the Bridgman Process for Flattening the Temperature Profile and Controlling the Columnar Grain Structure of Directionally Solidified Ni-Based Superalloys. Materials 2019, 12, 935. [CrossRef]

13. Ma, D.; Wang, F.; Wu, Q.; Bogner, S.; Bührig-Polaczek, A. Innovations in Casting Techniques for Single Crystal Turbine Blades of Superalloys. In Superalloys 2016; Wiley: Hoboken, NJ, USA, 2016; pp. 237-246. 
14. Epishin, A.I.; Link, T.; Noltze, G.; Svetlov, I.L.; Bokshtein, B.S.; Rodin, A.O.; Salivan-Neumann, R.; Öder, G. Diffusion processes in multicomponent nickel-base superalloy-nickel system. Phys. Met. Met. 2014, 115, 21-29. [CrossRef]

15. Schulze, C.; Feller-Kniepmeier, M. Transmisson electron microscopy of phase composition and lattice misfit in the Re-containing nickel-base superalloy CMSX-10. Mater. Sci. Eng. A 2000, 281, 204-212. [CrossRef]

16. Rappaz, M.; Gandin, C.-A.; Gandin, C.-A. Probabilistic modelling of microstructure formation in solidification processes. Acta Met. Mater. 1993, 41, 345-360. [CrossRef]

17. Bhadeshia, H.K.D.H.; Mackay, D. Estimation of the $\gamma$ and $\gamma^{\prime}$ lattice parameters in Nickel-base superalloys using neural network analysis. ISIJ Int. 1998, 38, 495-502.

18. Vehn, M.; Dedecke, D.; Paul, U.; Sahm, P. Undercooling Related Casting Defects in Single Crystal Turbine Blades. Superalloys 1996, 471-479.

19. Kermanpur, A.; Rappaz, M.; Varahram, N.; Davami, P. Thermal and grain-structure simulation in a land-based turbine blade directionally solidified with the liquid metal cooling process. Met. Mater. Trans. A 2000, 31, 1293-1304. [CrossRef]

20. Caron, P.; Khan, T. Evolution of Ni-based superalloys for single crystal gas turbine blade applications. Aerosp. Sci. Technol. 1999, 3, 513-523. [CrossRef]

21. Szeliga, D.; Kubiak, K.; Burbelko, A.; Motyka, M.; Sieniawski, J. Modeling of directional solidification of columnar grain structure in CMSX-4 nickel-based superalloy castings. J. Mater. Eng. Perform. 2014, 23, 1088-1095. [CrossRef]

22. Reed, R.; Matan, N.; Cox, D.; Rist, M.; Rae, C. Creep of CMSX-4 superalloy single crystals: Effects of rafting at high temperature. Acta Mater. 1999, 47, 3367-3381. [CrossRef]

23. Albrecht, R.; Rak, J.; Bogdanowicz, W.; Gancarczyk, K.; Sieniawski, J.; Kubiak, K.; Lelątko, J. Effect of Creep on Crystallographic Orientation in Single Crystal Superalloy. Acta Phys. Pol. A 2016, 130, 1094-1096. [CrossRef]

24. Le Graverend, J.-B.; Jacques, A.; Cormier, J.; Ferry, O.; Schenk, T.; Mendez, J. Creep of a nickel-based single-crystal superalloy during very high-temperature jumps followed by synchrotron X-ray diffraction. Acta Mater. 2015, 84, 65-79. [CrossRef]

25. Völkl, R.; Glatzel, U.; Feller-Kniepmeier, M. Measurement of the lattice misfit in the single crystal nickel based superalloys CMSX-4, SRR99 and SC16 by convergent beam electron diffraction. Acta Mater. 1998, 46, 4395-4404. [CrossRef]

26. Zhang, H.; Xu, Q. Simulation and Experimental Studies on Grain Selection and Structure Design of the Spiral Selector for Casting Single Crystal Ni-Based Superalloy. Materials 2017, 10, 1236. [CrossRef] [PubMed]

27. Callister, W.; Rethwisch, D. Materials Science and Engineering an Introduction; John Wiley \& Sons: New York, NY, USA, 2007.

28. Okazaki, M.; Take, K.; Kakehi, K.; Yamazaki, Y.; Sakane, M.; Arai, M.; Sakurai, S.; Kaneko, H.; Harada, Y.; Itoh, A.; et al. Collaborative research on thermo-mechanical and isothermal low-cycle fatigue strength of ni-base superalloys and protective coatings at elevated temperatures in The Society of Materials Science, Japan (JSMS). In Thermomechanical Fatigue Behavior of Materials; ASTM International: West Conshohocken, PA, USA, 2003.

29. Ying, S.; Ma, L.; Sui, T.; Papadaki, C.; Salvati, E.; Brandt, L.R.; Zhang, H.; Korsunsky, A.M. Nanoscale Origins of the Size Effect in the Compression Response of Single Crystal Ni-Base Superalloy Micro-Pillars. Materials 2018, 11, 561. [CrossRef]

30. Kang, M.; Gao, H.; Wang, J.; Ling, L.; Sun, B. Prediction of Microporosity in Complex Thin-Wall Castings with the Dimensionless Niyama Criterion. Materials 2013, 6, 1789-1802. [CrossRef]

31. Szczotok, A.; Rzychon, T.; Cwajna, J. Quantitative evaluation of y'phase in CMSX-4 superalloy. Inz. Mater. 2010, 31, 686-690.

32. Łagiewka, E. Fundamentals of X-ray, Electron and Neutron Diffraction; Silesian University Press: Katowice, Poland, 2015.

33. Yang, W.; Xu, M.; Bai, H.; Meng, Y.; Wang, L.; Shi, L.; Pei, Y.; Zhang, J.; Zheng, L. Concentration depth distribution of grain boundary segregation measured by wavelength dispersive $\mathrm{X}$-ray spectroscopy. Ultramicroscopy 2015, 159, 432-437. [CrossRef]

34. Frackowiak, J.E. Studies of B2 and DO3 Type Superstructures Using the Mössbauer Effect Method; Silesia University Press: Katowice, Poland, 1993. 
35. Gancarczyk, K.; Albrecht, R.; Berger, H.; Szeliga, D.; Gradzik, A.; Sieniawski, J. Determination of crystal orientation by $\Omega$-scan method in nickel-based single crystal turbine blades. Metall. Mater. Trans. 2017, 48, 5200-5205. [CrossRef]

36. Lamm, M.; Singer, R. The Effect of Casting Conditions on the High-Cycle Fatigue Properties of the Single-Crystal Nickel-Base Superalloy PWA 1483. Metall. Mater. Trans. 2007, 38, 1177-1183. [CrossRef]

37. Guo, X.; Fu, H.; Sun, J. Influence of solid/liquid interfaces on the microstructure and stress-rupture life of the single-crystal nickel-base superalloy NASAIR 100. Metall. Mater. Trans. 1997, 28, 997-1009. [CrossRef]

38. Huang, M.; Zhang, G.; Wang, D.; Dong, J.; Wang, L.; Lou, L. Microstructure and Stress-Rupture Property of Large-Scale Complex Nickel-Based Single Crystal Casting. Acta Metall. Sin. 2018, 31, 887-896. [CrossRef]

(C) 2019 by the authors. Licensee MDPI, Basel, Switzerland. This article is an open access article distributed under the terms and conditions of the Creative Commons Attribution (CC BY) license (http://creativecommons.org/licenses/by/4.0/). 